\title{
Caminhos cruzados entre intermidialidade, star system e música no Ébrio de Gilda de Abreu
}

\section{Margarida Maria Adamatti}

Doutora; Universidade Federal de São Carlos, São Carlos, SP, Brasil margaridaadamatti@gmail.com

\section{Resumo}

Em 1935, o tenor Vicente Celestino lançou a música $O$ Ébrio. Aproveitando o grande sucesso alcançado, a canção foi transposta para o universo do teatro, do cinema, da literatura e da telenovela ao longo de 30 anos. O artigo toma a intermidialidade, o conceito de transposição e o star system como ferramenta de análise do filme $O$ Ébrio de Gilda de Abreu. A partir da construção da persona de Celestino, na materialidade do filme, no eu lírico da canção e na representação da vida midiática do ator, o objetivo é demonstrar como a presença em cena do astro nas sequências musicais junto à transposição intermidiática se fazem presentes na forma cinematográfica. $O$ estudo demonstra como a presença em cena do astro nas sequências musicais fornece um fator de compensação à ausência do hic et nunc.

\section{Palavras-Chave:}

O Ébrio. Gilda de Abreu. Vicente Celestino. Intermidialidade.

\section{Introdução e metodologia}

Se geralmente os estudos em torno da intermidialidade abordam o diálogo entre duas mídias, comparativamente os Ébrios do casal Vicente Celestino e Gilda de Abreu oferecem um projeto integrado em cinco mídias: rádio, teatro, cinema, livro e televisão. Ao longo de três décadas, a famosa canção de Vicente Celestino foi remediada (BOLTER; GRUSIN, 2000) para outras mídias com enorme audiência. Em 1935, a música estreou na Rádio Guanabara e no ano seguinte virou disco. Levada aos palcos em 1941, a "canção teatralizada" de Celestino permaneceu em cartaz por quase cinco meses e foi reencenada até os anos sessenta. Em 1946, Gilda de Abreu transpôs a história para as telas e conseguiu obter um dos maiores sucessos de bilheteria do cinema brasileiro (PIZOQUERO, 2006; 
PAIVA, 1989). A história do homem abandonado pela mulher, que se entrega à bebida, teve direito a uma continuação escrita por Gilda de Abreu em Alma de Palhaço, na forma de radionovela e de livro (ABREU, [195-?]). Vinte anos depois da estreia no rádio, Celestino participou como cantor do primeiro capítulo da telenovela $O$ Ébrio (1965-1966), levada ao ar pela TV Paulista em 1965. Isso sem citar as inúmeras apresentações da peça em circosteatro até os anos sessenta.

De comum entre essas adaptações, os Ébrios intermidiáticos estruturam-se em torno da transposição da canção original pela voz do famoso tenor Vicente Celestino. Ele começou na carreira em 1914, apresentando-se em casas de chope. Nos anos vinte, o nome do astro servia de letreiro luminoso no teatro de revista da Praça Tiradentes, no Rio de Janeiro, o que significava um privilégio reservado somente aos campeões de audiência (TINHORÃO, 1981). Ainda nos anos sessenta, o cantor conseguiu lotar o estádio do Maracanã (GUERRA, 1994). Celestino foi uma figura intermidiática por excelência. Ele transitou pela ópera, pela opereta, pelo teatro de revista, pelos programas de rádio e pelo cinema.

Nesse sentido, a intermidialidade adéqua-se bem ao estudo do Ébrio, porque permite analisar as relações de interações, interferências e reciprocidades entre formas artísticas e midiáticas (CLÜVER, 2006). Neste artigo, realçamos as ligações entre o filme, a canção e a construção da vida midiática do ator Vicente Celestino. Concentramos nossa atenção a dois conceitos de intermidialidade: a transposição e as fronteiras transitórias. Klaus Clüver (2006) e Irina Rajewsky (2012) consideram a transposição um critério vindouro para avaliar a adaptação fílmica, seja de textos literários, teatrais ou novelizações. Com foco no processo de produção, observa-se como a transformação de uma mídia é definida no substrato de outra. Isto é, como o texto ou filme constitui a fonte da recém-formada configuração midiática. Longe de uma preocupação com a fidelidade em relação ao original, a transposição envolve a mudança de signos ou de mídia para outro formato (CLÜVER, 2006). Procura-se compreender, por exemplo, quais foram as razões que levaram à forma adquirida na nova mídia, tendo como princípio o texto alvo. Nesse sentido, o cinema é visto como o resultado da convergência e transformação de elementos de diferentes mídias. Não se trata somente de um estudo comparativo entre a música $O$ Ébrio e o filme, mas de observar como a presença da canção surge na forma cinematográfica.

Se num primeiro momento, os estudos de intermidialidade procuraram realçar grandes categorias de análise, como a transposição, a combinação e a referência ${ }^{1}$, a

${ }^{1}$ Para maiores detalhes, ver a classificação proposta por Irina Rajewsky (2012). 
tendência seguinte foi observar o cruzamento de fronteiras entre as mídias como uma dissolução de espaços (DINIZ; VIEIRA, 2012) ou um entre-lugar oscilante, instável e transitório (PETHÖ, 2011).

Seguimos a perspectiva apontada por Jürgen Müller (2012) de abordar a intermidialidade como um Such-Konzept (Conceito de Busca) e um método interdisciplinar, capaz de enfrentar as conexões traçadas entre os filmes e as demais formas artísticas e midiáticas. Aliado a esse percurso, adaptamos o conceito de intermidialidade enquanto fronteira móvel para analisar os espaços difusos entre a atuação do astro e do personagem de Vicente Celestino. Afinal grande parte do sucesso das transposições midiáticas do Ébrio surge em torno da presença em cena do famoso tenor. Assim, é no interstício da performance do cantor que a ideia de intermidialidade possibilita repensar os espaços fronteiriços deixados em aberto pela análise fílmica tradicional.

Portanto, partimos de uma lacuna entre os estudos de intermidialidade no cinema, de transposição midiática e de star system, para analisar como a presença em cena do astro e o acesso integral à canção dentro do filme auxiliam a preencher as lacunas da transformação para as telas. 0 artigo estrutura-se em duas partes: a construção da persona de Vicente Celestino dentro e fora das telas e o processo de junção e descolamento entre ator e personagem nas sequências musicais. 0 estudo é feito em várias mídias: tanto na materialidade do filme, quanto no eu lírico das canções e na representação da vida midiática do ator, isto é, na sua biografia, na imagem representada na imprensa e nas estratégias de propaganda. Esse conjunto demonstra como o estrelismo tornou singular a transposição musical do Ébrio. A noção de star system utilizada aqui não pretende encontrar a unicidade da estrela em sua vida pessoal como garantia de verdade. Nosso intuito é investigar o processo de construção da autenticidade do astro.

\section{Análise da construção do star system de Vicente Celestino}

Pensando no personagem do Ébrio, dois estereótipos são importantes: o do morador de rua e o do alcoólatra. Em alguns momentos da trajetória midiática de Celestino, as estratégias de propaganda deram vazão a uma transferência entre o papel interpretado e sua persona. Em 1919, o ator saiu pelas ruas do Rio de Janeiro vestido de "mendigo" para fazer a propaganda da peça Flor da noite de Oduvaldo Vianna (PIZOQUERO, 2006). Retomando a mesma estratégia, no dia do lançamento do filme $O$ Ébrio, o astro transvestiu- 
se do personagem e pediu esmolas aos pedestres na porta do estúdio da Cinédia, no Rio de Janeiro.

Se nesses dois casos as estratégias de propaganda estimularam a mescla entre ator e personagem, Gilda de Abreu (2003), no livro Minha vida com Vicente Celestino, narrou seu receio de que recaísse sobre o marido a pecha de alcoólatra exatamente por causa do Ébrio. Se o processo realmente aconteceu, como ela diz, a autora insiste em enfatizar que o astro era abstêmio. Indo na mesma direção, Vicente Celestino mostrou ao jornalista Guido Guerra (1994) um armário cheio de bebidas alcoólicas de todos os tipos, enviadas pelos fãs, que o confundiam com seu mais famoso personagem, mesmo vinte anos depois. Talvez essa imagem do Ébrio atrelada a Celestino realmente tenha permanecido por mais tempo na memória do público. Na revista O Cruzeiro, por exemplo, ao longo dos anos, leitores e cartunistas traçam um paralelo entre o filme de Gilda de Abreu, o tenor e a bebedeira.

0 processo de construção da persona de Vicente Celestino completa-se com o livro $A$ vida de Vicente Celestino (ABREU, [194-?a]), que parece ter sido escrito por Gilda de Abreu durante as filmagens do Ébrio (ABREU, 2003) ${ }^{2}$. Trata-se de uma versão romantizada sobre o cantor ${ }^{3}$. A publicação teria sido reeditada cinco vezes até 2003 com o título Minha vida com Vicente Celestino, sempre com grande sucesso (GUERRA, 1994). A obra possibilita analisar a personalidade midiática do tenor, sem procurar pela veracidade das histórias contadas. Guido Guerra (1994) observa que Gilda constrói uma imagem do cantor como o "coitadinho". Os colegas roubavam suas canções, destinavam porões alagados como camarim, jogavam sua casaca dentro de um tonel de piche segundos antes de entrar em cena, ou simplesmente abriam um alçapão para o ator cair dentro. Assim o livro de Abreu possui os componentes necessários para formar a imagem de Celestino como a bondade perseguida pela inveja, e esse traço da personalidade será repetido em várias mídias, como veremos.

Certa vez, por exemplo, Celestino teria se envolvido em uma briga após receber um prêmio por ser um aluno aplicado. Apesar de ganhar a disputa, o pequeno Vicente perdeu sua medalha de honra, teve as roupas rasgadas e enlameadas e ainda ficou de castigo.

\footnotetext{
2 Não consta o ano de publicação da primeira edição do livro. Essa versão termina com a expectativa e os anseios da autora sobre a recepção do filme de 1946. Portanto, é provável que o livro tenha sido escrito nesse período. Para fins de citação bibliográfica, utilizamos a última reedição do mesmo livro de Gilda de Abreu (2003), que relata a vida do cantor até seu falecimento.

30 excesso de romantização das narrativas sobre a vida dos atores de cinema caracteriza a produção destinada ao consumo dos fãs. Muitas vezes sob a forma camuflada de informação, surge uma substância romanesca ou dramática, ficcionalizando a vida das estrelas (MORIN, 2005). Através das situações romanceadas, esses textos fornecem uma estrutura afetiva calcada na transferência entre ator e personagem com o intuito de provocar a ilusão do público de participar dos eventos citados. Sobre a romantização da vida das estrelas nos textos da imprensa brasileira, ver Adamatti (2008).
} 
Provavelmente, retomando esse episódio, Gilda contou um incidente muito parecido no livro O Ébrio (ABREU, [194-?b]), para explicar os infortúnios do personagem Gilberto por meio da vilania de um garoto invejoso e cheio de ódio. Discretamente, em um labirinto de citações, constrói-se, assim, uma analogia sutil entre a vida do ator e do personagem.

Esses paralelos frisam, especialmente, a personalidade de um homem sofredor. No livro Minha vida com Vicente Celestino, Gilda de Abreu (2003) traz certa noção de predestinação e destino, colocando-se no papel de corrigir as injustiças cometidas contra o marido. Depois de narrar seu desânimo por causa de problemas de saúde e de dificuldades financeiras, ela explica aos leitores a necessidade de continuar sua luta: "porque eu sabia que ainda era necessário viver. Precisava viver, pois o que me propusera a realizar quando casei com Vicente ainda não havia sido concluído". Naquele momento, ela jurou "intimamente diante do altar que me empenharia para elevar Vicente ao lugar que merecia ocupar, pelo seu talento e honestidade, que sempre sobrepujaram as injustiças que ele sofreu" (ABREU, 2003, p. 112).

Observa-se aqui certa construção de um homem sofredor que encontra ressonância com as músicas de Celestino. 0 eu lírico das canções surge ligado ao pessimismo, ao homem sincero, autêntico, traído, sofredor e de bom coração. Outras temáticas também estavam presentes, como o tema da ingratidão como resposta ao afeto, o abandono, a degradação e o vazio depois da aceitação da derrota (GUERRA, 1994).

É digno de nota que o livro de Gilda de Abreu procura afirmar o grande sucesso de Vicente Celestino e a adoração do público, mas aos poucos a autora narra várias histórias de pequenos fracassos profissionais, de perdas financeiras, de "injustiças" e esquecimentos dos críticos. Constrói-se, assim, indiretamente, um processo de transferência entre a vida midiática do cantor e o teor pessimista das melodias. Para completar esse quadro de similitudes entre ator e eu lírico, as músicas de Celestino eram compostas na primeira pessoa do singular.

Se a imagem do homem sofredor era repetida em várias canções de Celestino, em um artigo da revista A Cena Muda de 1941 é possível encontrar outro componente relevante da personalidade midiática do tenor. Exatamente no ano da estreia da peça $O E$ Ébrio, a jornalista Sylvia Moncorvo realça um traço importante para a estrutura do estrelismo do tenor, que será remediado em várias mídias: 
É mesmo autêntico tenor que nos comove, nos inspira, traz ao nosso coração a nostalgia brasileira tão genuína e tão sincera. 0 nosso querido primeiro tenor, pessoalmente, é de uma bondade tão simples que encanta. Coração filigranado e doce, alma ingênua, simplicidade encantadora [...]. A sua alma tem o misticismo das pulcridades latentes. Compreende a vida sob um destino harmonioso o elogio da bondade sobre a premeditação de realizar em sonoros motivos a sua humana trajetória (MONCORVO, 1941, p. 21).

A informação que interliga o artigo inteiro é a sinceridade. Trata-se de uma palavra chave para o estrelismo, assim como a ideia de bondade e de simplicidade (DYER, 2004). Esse traço da personalidade surge enfatizado no filme $O$ Ébrio (1946) tanto no enredo, como nas imagens e na canção, para frisar a incapacidade do personagem Gilberto de suportar a falsidade que estraçalha sua vida, após a traição da esposa. Enquanto isso, o público poderia comparar o personagem com o astro, que mesmo "perseguido", dava a volta por cima, com grande sucesso.

Assim como essa matéria de Cena realça a sinceridade de Celestino, os versos da canção $O$ Ébrio, em 1935, já traziam a mesma temática, por meio da oposição à falsidade: “E nos parentes... confiava sim!/E hoje ao ver-me na miséria tudo vejo então/ 0 falso lar que amava e a que a chorar deixei./ Cada parente, cada amigo, era um ladrão/Me abandonaram e roubaram o que amei" (CELESTINO, 1935). E mais à frente, o narrador em primeira pessoa completa: "Apedrejado pelas ruas vivo a sofrer/ Não tenho lar nem parentes, tudo terminou".

As informações sobre o homem sincero, de bom coração e sofredor não apontam somente para o eu lírico das canções de Vicente Celestino, mas também para a construção de sua personalidade midiática pelas mãos de Gilda. Tanto na primeira versão de $A$ vida de Vicente Celestino (ABREU, [194-?a]), quanto na última reedição do livro, Abreu retoma a preocupação dos pais do futuro tenor com a sensibilidade do filho. No primeiro contato com o gramofone, ainda criança, ele teria ficado tão encantado que os “[...] paes ficaram preocupados. Aquele pequeno era sensível demais! Tudo o impressionava tudo o emocionava! Aquilo assim, ia de mal a pior." (ABREU, 2003, p. 27).

Esse vestígio de alma sensível de Celestino contamina o personagem do livro $O$ Ébrio, descrito da mesma maneira por Gilda de Abreu ([194-?b], p. 34). Quando criança, Gilberto cura seu porquinho de estimação e chora profundamente de alegria. Preocupada, a mãe comenta com o marido: "Como é sensível nosso filho! Como irá sofrer na vida". Como o pai, o personagem tem um espírito "franco e leal" e não percebe a inveja dos parentes. Se Gilberto 
faz medicina para "fazer o bem a todo mundo", como aparece no livro, o cantor Vicente Celestino é caridoso com os carentes, faz shows para arrecadar fundos aos necessitados, visita leprosos e pessoas a beira da morte em hospitais.

Esse tipo de informação sobre a sensibilidade apurada do tenor é reenfatizada diversas vezes no livro Minha vida com Vicente Celestino, até que a própria escritora sintetiza a personalidade do marido da seguinte forma:

Quando Vicente me contava, com sua comovedora e costumeira simplicidade, num atropelo de palavras, sua gratidão por todos aqueles que manifestavam carinho por ele, eu sentia sua sinceridade [...]. Confiante, simples, sem vaidade, sincero, bom como um bloco de ouro bruto! (ABREU, 2003, p. 103).

Essa informação a respeito da sinceridade do eu lírico e da personalidade do astro é repetida não só no enredo, mas também nas imagens do filme $O$ Ébrio (1946). Com este recurso, Gilda de Abreu mostra, de maneira recorrente, o personagem Gilberto rodeado de crianças, como se vê abaixo:

Figura 1 - Cenas do filme $O$ Ébrio: sequência entre Gilberto e a Princesinha e imagens no
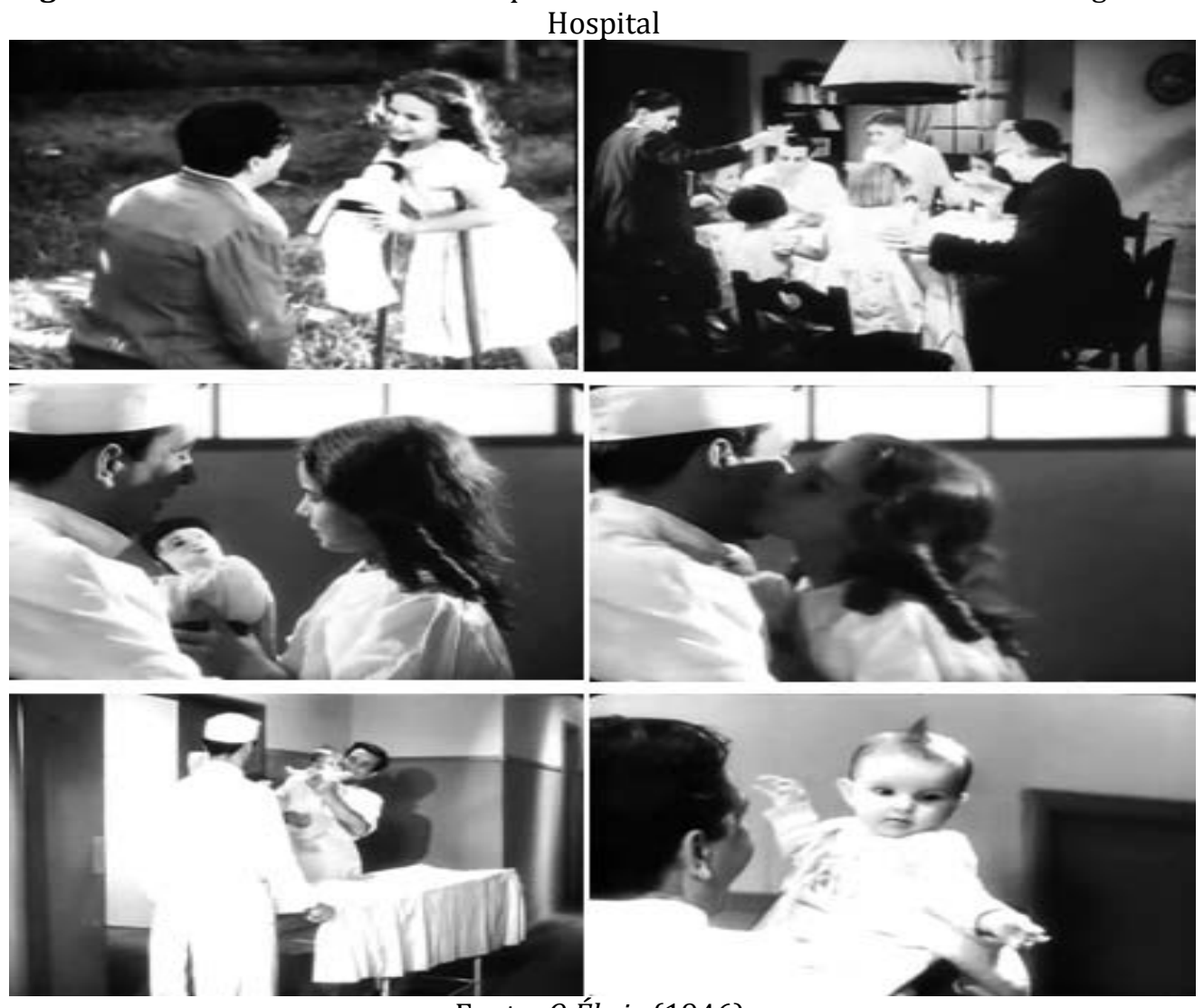

Fonte: $O$ Ébrio (1946). 
Quando insiste em interligar Gilberto às crianças, o filme tenta autenticá-lo por derivação, como uma pessoa sincera e verdadeira. Além disso, o roteiro fornece outros exemplos de sua personalidade. Gilberto é totalmente bom e sincero. Mal sabe flertar, opera as pernas de uma menina com deficiência e ajuda os parentes interesseiros que lhes fecharam a porta, quando ele mais precisou. Na cena final, o personagem ainda devolve à esposa traidora um cordão, símbolo de seu amor.

A questão da sinceridade, no filme, pode ser analisada a partir da própria dinâmica do star system. Em alguns casos, o estrelismo frisa a continuidade entre ator e personagem. Em outros momentos, a construção da estrela faz referência ao drama moral fora da tela ou aponta para a vida pessoal como garantia do tipo ao qual ela pertence. É dessa forma que um astro pode provar sua sinceridade ao abrir um colapso na divisão entre a autenticidade do ator e a do papel interpretado (DYER, 2004). É exatamente na lacuna entre o eu, o personagem e a aparência da persona que se produz parte do significado da estrela e uma expectativa em torno da noção individual de identidade. Dessa maneira, o ator passa a intervir em um estado fronteiriço entre sua personalidade e a vida autenticada na representação. Quando, por exemplo, interpreta uma figura parecida com a sua, o olimpiano pode contribuir com a ilusão da existência do personagem, gerando um tipo de encaixe entre o astro como imagem e como encarnação de um papel.

Da curiosidade inicial do público, de ver como o famoso tenor iria representar um homem embriagado, poderia surgir uma indagação de qual autêntico seria esse papel. Uma mescla importante para o estrelismo de Celestino aparece em torno da interpretação na primeira pessoa do eu lírico e no tipo de atuação. Sem procurar aqui por uma coincidência entre ator e personagem, a ambivalência entre esses dois polos é encarregada de instigar o interesse pelo estrelismo.

Não procuramos por uma autenticidade do ator em termos de naturalismo. Afinal, a voz de Celestino é excessivamente radiofônica e a interpretação como bêbado parece muito cambaleante. Contudo, essas características não surgem como uma deficiência em termos de atuação, mas como parte da interpretação do tenor que representa um bêbado. A autenticidade surge, nesse sentido, como parte da estratégia de divulgação do star system.

Aqui é necessário abrir um parêntese explicativo sobre o conceito de autenticidade proposto. Se o sentido lato geralmente denota algo original, genuíno, de propriedades mágicas para opor-se à falsificação (KIVY, 1997, TARUSKIN, 1995), muitas vezes o termo traz no universo musical certa recorrência à ideia de fidelidade, seja ao compositor, a sua 
performance ou à época em que viveu. Noutros momentos, a autenticidade surge em sentido autoral, como fidelidade ao performer, por ser o único a produzir sons daquele modo em especial (KIVY, 1997). Longe de debater a autenticidade artística no sentido de fidelidade a uma época ou a um autor, nosso interesse recai sobre a discussão a partir dos astros. Para Richard Dyer (DYER, 2004; 1991a; 1991b), a autenticidade surge como elemento crucial para fazer funcionar o estrelismo e legitimar os valores enfatizados pelos olimpianos. Portanto, vemos a autenticidade como parte da estratégia do star system de criar similitudes entre a interpretação do ator e sua vida midiática. 0 processo refere-se ao modo como a estrela atua, estabelecendo uma correspondência com a apresentação do personagem. Além disso, a autenticidade traz também as normas sociais daquele tempo e os valores corporificados pelo ator enquanto tipo social.

Construída em torno da personalidade "sincera" do astro, a interpretação de Vicente Celestino frisa a exterioridade da persona fora da tela. Dessa forma, era possível incentivar um duplo processo de conversão do tenor em personagem. Talvez, até como signo não programado, a atuação de Celestino, na cena final, demonstra sempre que vemos o astro atuar como bêbado. Esse tipo de performance aponta para o diálogo estabelecido com uma mídia externa ao cinema, no caso a do cantor radiofônico.

Como um componente fundamental do estrelismo, essas estratégias procuram instigar o espectador a rever o filme e encontrar nuances da personalidade do ator no personagem. Portanto, a própria construção da autenticidade depende de um estado constante de ambiguidade na fronteira entre o papel interpretado e o astro. Dessa forma, o star system procura criar no público o hábito de decifrar o segredo da identidade do ator (DECORDOVA, 2001). No caso de Celestino, cabe à sua personalidade sincera e autêntica interligar o cantor e o personagem. De uma possível indagação se o tenor seria tão sincero quanto o personagem, o fã poderia ficar mais curioso para ver o cantor interpretar os infortúnios de Gilberto.

Fortalecida por essa série de repetições, a dúvida sobre a similitude entre ator e papel interpretado pode auxiliar a autenticar o personagem. No entanto, como o enigma é solucionado apenas parcialmente, a personalidade do astro nunca estará completamente disponível. De acordo com Richard DeCordova (2001), com o star system, o público paga para ter acesso à identidade do intérprete. Contudo, a personalidade da estrela não pode ser revelada por inteiro, a partir de uma única obra. É preciso ter o costume regular de ir ao cinema, comparando dados sobre a aparência do ator entre os filmes. DeCordova (2001) 
mostra que esta constituição da identidade é feita, também, pela propaganda e pelas revistas de fãs. No caso de Celestino, o espectador tinha acesso às músicas do tenor por meio do rádio e dos discos.

0 jogo de informações entre a personalidade do astro e a do papel interpretado auxilia na criação da legitimidade do personagem. Pode-se dizer que tal operação surge como garantia da verdade do discurso do estrelismo. Nesse sentido, os textos da mídia cumprem a função de ajudar a construir afirmações móveis e uma autenticação flutuante do astro. Mesmo quando o espectador comprova que a estrela não é como aparece na tela, o processo reforça mais ainda a imagem criada. No caso de Celestino, a autenticidade pela ambivalência surge ligada à personalidade. Se a sinceridade constitui o traço proeminente do star system do tenor, vê-se o quanto o regime de reciprocidade no caso de Celestino não é, de maneira alguma, plano, mas sedimentado em uma série de afirmações móveis entre o personagem, o ator e o eu lírico das canções.

\section{A presença do astro nas sequências musicais do Ébrio}

Depois de abordar a configuração do estrelismo de Vicente Celestino, a segunda parte do artigo observa como nas sequências musicais o processo recíproco de junção e descolamento entre ator e personagem incorpora determinadas características da transposição midiática como elemento de constituição da montagem cinematográfica. 0 estudo da performance teatral (MOSTAÇO, 2009; DYER, 2004) inclui os recursos utilizados pelos atores para encarnar o personagem, tais como a vestimenta, a expressão fisionômica, os gestos, a postura, o movimento corporal, a tipificação física e a psicológica.

No campo do cinema, Richard Dyer (2004) retoma os estudos sobre a distinção formal dos tipos de performance para abordar o fenômeno do estrelismo. Para empreender sua busca, Dyer baseia-se em observações sobre os tipos de performance das personagens do romance. Longe de se preocupar com a composição do papel, há um especial interesse pela construção da performance entre ator e personagem. 0 autor conclui que a atuação dos astros acentua seu estilo particular entre os filmes, num repertório específico de gestos, entonações, cujo elemento inerte é a aparência, o som particular da voz e o estilo da roupa.

O fazer artístico de Vicente Celestino nas sequências musicais do Ébrio surge como a integração entre a prática vocal de repetição, a execução técnica e a interpretação, descrita por Mostaço (2009). Nesse sentido, sua performance integra o conhecimento racional e 
intuitivo, a tradição, a emoção, a sensibilidade e a cultura do executante (LIMA, 2006). A atuação de Celestino no filme está ligada tanto a essa prática da execução técnica da música, quanto à sua interpretação em relação à emoção. Essa peculiaridade nos conduz a observar o trabalho do performer enquanto intérprete, cantor e ator. Contudo, não iremos debater a prática da interpretação artística por si mesma. Desse universo vastíssimo, escolhemos focalizar a performance a partir das fronteiras transitórias entre a presença do astro e do personagem nas sequências musicais. Tomamos como parâmetro os comentários de Richard Dyer (2004) sobre o papel da performance musical como um indicador da autenticidade da estrela, sem comparar cada detalhe específico da ação do filme com o ator e o papel. Para tornar as fronteiras entre astro e personagem mais porosas, $O$ Ébrio recorre com frequência à função de duplo com o ator (MORIN, 2005). Esse processo está sedimentado no paralelo entre a vida midiática do tenor e do personagem, que como ele, é um famoso cantor de rádio. Celestino interpreta um estudante de medicina falido que vaga pelas ruas do Rio de Janeiro, sem ter o que comer e onde dormir. A virada na trama acontece quando Gilberto compõe uma música autobiográfica denominada Porta Aberta. A repercussão imediata é tão positiva que ele vence o concurso de rádio e se torna um cantor de sucesso. A canção foi escrita, especialmente, para o filme e teria repetido o sucesso da ficção na vida real, trazendo uma transferência do personagem como duplo do ator.

Esse processo contínuo de conversão do astro em maltrapilho ocorre, especialmente, nas sequências musicais, quando o cantor descola-se do papel interpretado. Nesses espaços, ocorre uma mescla de fronteiras entre a ficção e o acesso ao show como um simulacro do "ao vivo". Na primeira sequência musical, constrói-se a mudança do personagem sincero em astro. Celestino é chamado ao palco na condição de calouro. Demorando alguns segundos para subir, o apresentador mostra-se impaciente. Depois, exige o uso da gravata para cantar. Sem ter a indumentária necessária, Gilberto surge envergonhado de sua condição, de cabeça baixa. A reclamação do apresentador provoca uma grande gargalhada da plateia. Essa recepção constrói um paralelo entre a perseguição ao próprio Celestino, narrada por Gilda de Abreu (2003) em seu livro. Depois dos risos, o apresentador impõe silêncio com um gesto e expressa seus sentimentos de piedade pelo calouro, aproximando-se dele. É exatamente nesse momento que a cena aproveita o estereótipo do pobre coitado: 
Figura 2 - Cenas do filme $O$ Ébrio: na emissora de rádio

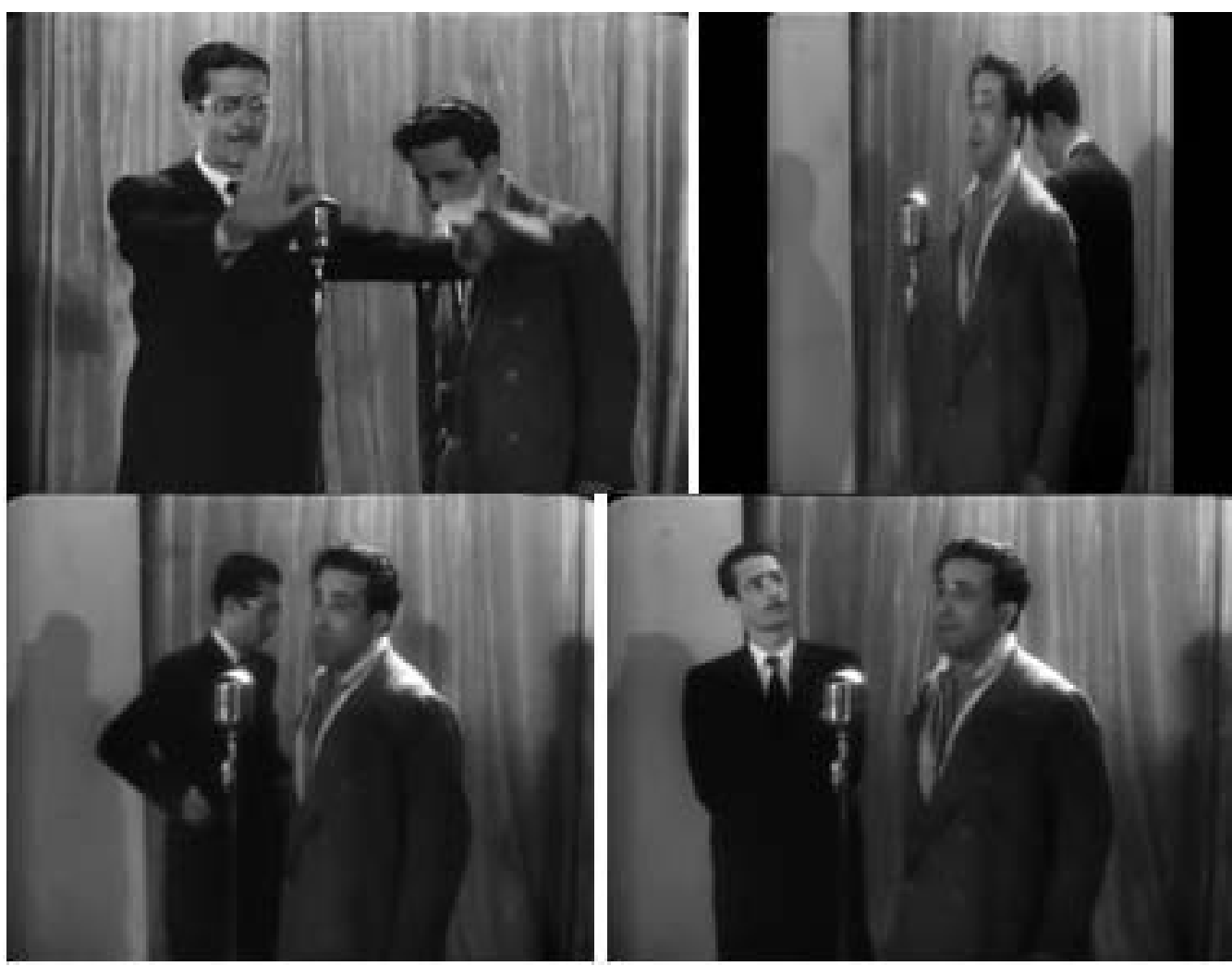

Fonte: 0 Ébrio (1946).

Por meio do olhar e dos gestos do apresentador do programa, é possível acompanhar sua mudança em relação ao calouro. Quando Gilberto começa a cantar, o apresentador anda atrás dele. Com isso, divide nossa atenção em relação à atuação. Embora não seja a maneira habitual de apresentar um astro em sua performance musical, a cena possibilita observar o nascimento de uma estrela. Trata-se do momento no qual o caminhar do apresentador do programa deixa de ser uma pausa de avaliação para se tornar uma manifestação de admiração. Nesse sentido, a prova do estrelato é a contemplação de terceiros, cuja fórmula será repetida mais de uma vez no filme.

As cenas seguintes são intercaladas de um pot-pourri, no qual Gilberto surge transfigurado em astro, bem vestido e de terno. É nesses momentos que vemos muito mais Vicente Celestino em cena do que o personagem. Ele leva no rosto um sorriso não só autoconfiante, mas também convencido de si. Não há mais sinal do pobre coitado, simplório e humilde. A cabeça não está mais baixa e o público pode contemplar Celestino de perto, observando minúcias de seu sorriso, dos gestos e do seu olhar. Nesse momento, ele parece 
muito mais um homem experiente do que o personagem inocente, acendendo a curiosidade dos fãs sobre sua personalidade midiática.

Figura 3 - Cenas do filme $O$ Ébrio: Gilberto na emissora de rádio
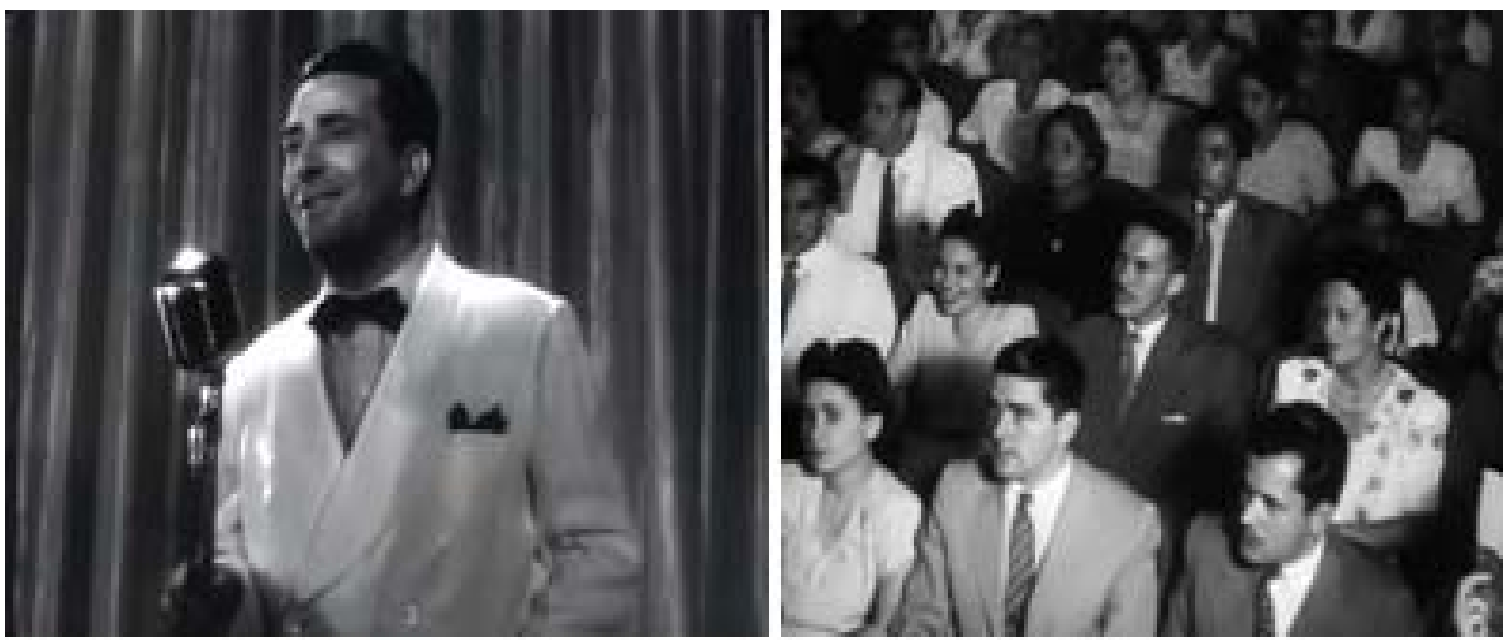

Fonte: 0 Ébrio (1946).

Na cena final, quando o homem embriagado conta sua história, ocorre o último momento de descolamento do personagem, na reconversão do morador de rua em cantor. A sequência traz a singularidade da presença do astro como possibilidade de tornar o acesso à música mais verossímil. Como nos primeiros musicais, a apresentação da canção é incorporada à diegese (CHION, 2002) e aponta uma integração total com o dizer. Trata-se da sequência mais importante, quando, finalmente, Vicente Celestino canta a música tema do filme. Ele reencontra a esposa, a perdoa, mas prefere continuar seu caminho de embriaguez, proferindo a famosa frase: "eu disse que perdoava, mas não disse que me reconciliava".

O detonador do início musical ocorre quando dois casais ricos entram no bar para se "divertir" à custa do infortúnio alheio. Eles pedem a Gilberto que conte sua história em troca de bebida. Nesse momento, ocorre a transição entre a narração do filme e o início da apresentação musical. Um segundo antes de começar a cantar, sucede uma transformação entre a atuação do ator e o momento no qual Vicente Celestino atua como ele mesmo. Quando o personagem toma um violão de um cliente, ele não interpreta mais o bêbado. Por acaso, surgem músicos na mesa ao lado. Acompanhados do som extradiegético de uma orquestra, eles começam a tocar seus instrumentos um segundo antes de Celestino cantar. Então, o astro abandona a voz alcoolizada do personagem e os clientes do bar contemplam 
com admiração, não o homem embriagado, mas o cantor. Nesse momento, vemos de perto o tenor interpretando o papel.

Como na sequência do apresentador do programa de rádio, os ricaços mudam de postura. Inicialmente, uma das mulheres volta seu corpo para trás com medo do homem embriagado. Depois, ela apoia os braços na mesa para contemplar o cantor. Se as pessoas literalmente param para ouvir Celestino, essa é a forma escolhida pelo filme para provar a presença em cena do astro, seja através do olhar dos ricos, ou da audiência popular, como se vê abaixo:

Figura 4 - Cenas do filme $O$ Ébrio na sequência final no bar
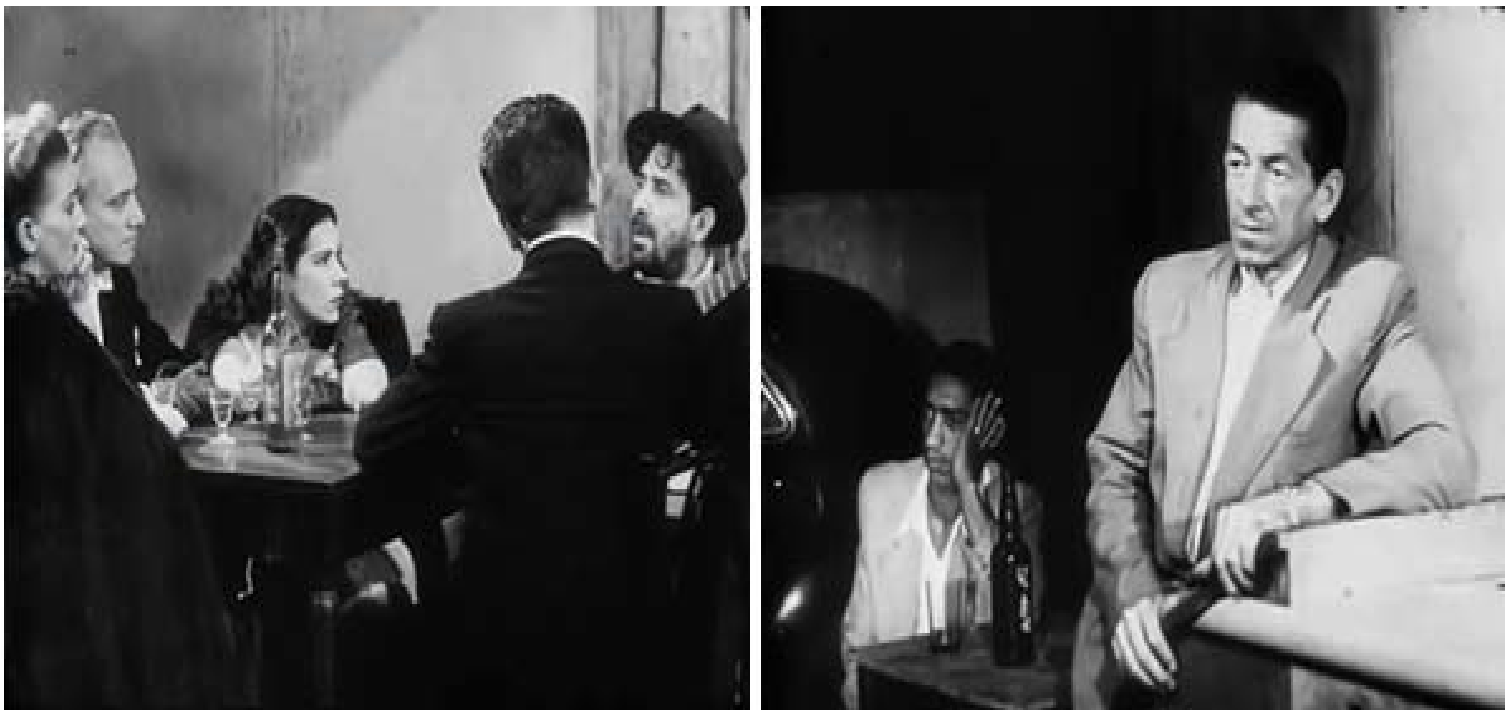

Fonte: O Ébrio (1946).

A sequência procura apropriar-se da memória musical do público pela identificação com a plateia em cena e pela repetição da canção título. Dessa forma, o filme parece criado em torno da expectativa de conseguir acesso à performance musical do astro. Mesmo depois de cantar a música tema, a melodia,os versos do Ébrio voltam, seja no diálogo copiado da letra da canção, seja nos créditos finais. Assim, o filme todo é uma grande mídia de repetição da música. Essa técnica de duplicação é típica não só da remediação (BOLTER; GRUSIN, 2000), mas também de Vicente Celestino. Ele costumava rememorar o vocabulário das canções nas letras escritas depois do Ébrio (GUERRA, 1994). Aqui, não está em jogo a originalidade da composição musical, mas a estratégia intermidiática voltada à familiaridade sonora do fã. Esse tipo de operação não era só de Vicente Celestino. Jane Feuer (1981) 
mostrou como os musicais da MGM jogavam com a iconografia da estrela e com a intertextualidade, repetindo títulos, danças e arranjos para avivar a memória do público.

No caso brasileiro, as estratégias de reavivamento da memória musical já estabeleciam vínculos vindouros entre a música popular, o teatro de revista, o disco e o rádio na primeira década do século XX (TINHORÃO, 1981). Ainda em 1906, Bastos Tigre teria sido o primeiro a conseguir um estrondoso sucesso do quadro de Mário Lino, Vem cá mulata, do teatro de revista Maxixe para os gramofones. Naquele contexto, as revistas cumpriram o papel de primeiras responsáveis pela divulgação de grandes sucessos da música popular, antecipando o lançamento dos cantores nos discos e no rádio. Assim, os compositores descobriram logo a vantagem de incluir suas músicas nos números do teatro de revista, como primeiro passo para torná-las nacionalmente conhecidas. Com o tempo, esse movimento podia sair não só do teatro de revista, mas também do rádio ou do próprio cinema, como foi o caso da música Porta aberta (1946) de Vicente Celestino que foi lançada primeiro no filme $O$ Ébrio (1946).

Essas estratégias de reavivamento da memória musical eram ampliadas com as possibilidades do cinema, apontando para o diferencial cinematográfico enquanto forma de acesso ao astro entre as mídias disponíveis naquele momento. Quando Gilda de Abreu lançou seu filme, o público podia escutar as músicas de Vicente Celestino pelo rádio ou pelos discos. No geral, a cada nova transposição midiática, o espectador tinha um ganho em relação à mídia anterior. No entanto, mesmo a peça de teatro $O$ Ébrio (1941) recorria aos discos do cantor nas sequências musicais, porque nem sempre o papel era interpretado por Celestino. Nesse sentido, o filme oferecia uma vantagem em termos de autenticidade e contemplação do astro. Trata-se da possibilidade de permitir o acesso simultâneo ao som da música e à imagem de Celestino, para os que não podiam vê-lo ao vivo no teatro.

Contudo, se os ganhos com a transposição musical parecem maiores, não se deve descartar as perdas no que tange à participação do ator teatral. Mesmo que o cinema não tenha a presença do ator de teatro no tempo presente, segundo André Bazin (1991), ele compensaria essa ausência com a equação psicológica e com a ampliação espaço-temporal. No artigo "Cinema e teatro", Bazin atualizou os comentários de Walter Benjamin (2000) sobre a diferença da performance teatral para a área cinematográfica, discutindo as possibilidades de substituição oferecidas pelo cinema à ausência do hic et nunc. Bazin (1991) descreve algumas dessas estratégias compensatórias, como a proximidade construída artificialmente pela câmera, o uso do close up, a fragmentação do espaço e a 
possibilidade de trazer o microscópico e o macroscópico por meio da imersão em cena do ator. Tomamos os comentários de André Bazin (1991), para examinar o papel da música e do star system como um substituto da presença em cena do ator teatral no tempo presente. Para os que não podiam ver Vicente Celestino ao vivo no teatro, o star system podia gerar um tipo de hic et nunc peculiar, quando aliado à transposição musical.

Contudo, Gilda de Abreu não usou a imersão do espectador por meio da fragmentação do espaço, como descreveu Bazin (1991). Ela preferiu intercalar quase cinco minutos da canção $O$ Ébrio com técnicas documentais de montagem. A somatória desses procedimentos, aliado à presença do astro e à transposição musical, surge como possibilidade de trazer elementos compensadores do tempo presente do teatro. Não se trata de um uso original criado por Gilda de Abreu. Nosso intuito, portanto, é o de analisar como a cineasta organizou a transposição para o cinema através da montagem. Na cena final, Abreu parece se preocupar mais em proporcionar o acesso completo à música. A sequência não tem a quebra da quarta parede, como acontecia em muitos musicais. Celestino prefere cantar para os clientes do bar sem encarar a câmera. 0 viés documental dessa cena cria um tipo de gênero híbrido dentro da ficção. A mudança de registro tenta trazer ao público a sensação de participar de uma apresentação "ao vivo" de Vicente Celestino no cinema.

O Ébrio utiliza algumas técnicas do musical descritas por Jane Feuer (1981), como o mito da integração. Trata-se da maneira de expor uma ponte entre a atuação do astro e a participação do público. Se a audiência que assiste ao show dentro do filme expressa uma adulação ao número musical, o processo procura fornecer ao espectador a sensação de tomar parte da apresentação e de se identificar com os figurantes. Esse processo corre paralelo ao resurgimento do critério da sinceridade. Para autenticar a cena, a montagem recorre muito à presença das crianças, mais puras ainda que Gilberto. Uma delas encara a câmera por um momento, em seguida desvia o olhar e coloca a mão no queixo. Quebrando por um segundo com a quarta parede, ela fornece uma sensação de registro documental "ao vivo": 
Figura 5 - Cenas do filme $O$ Ébrio: as crianças no bar
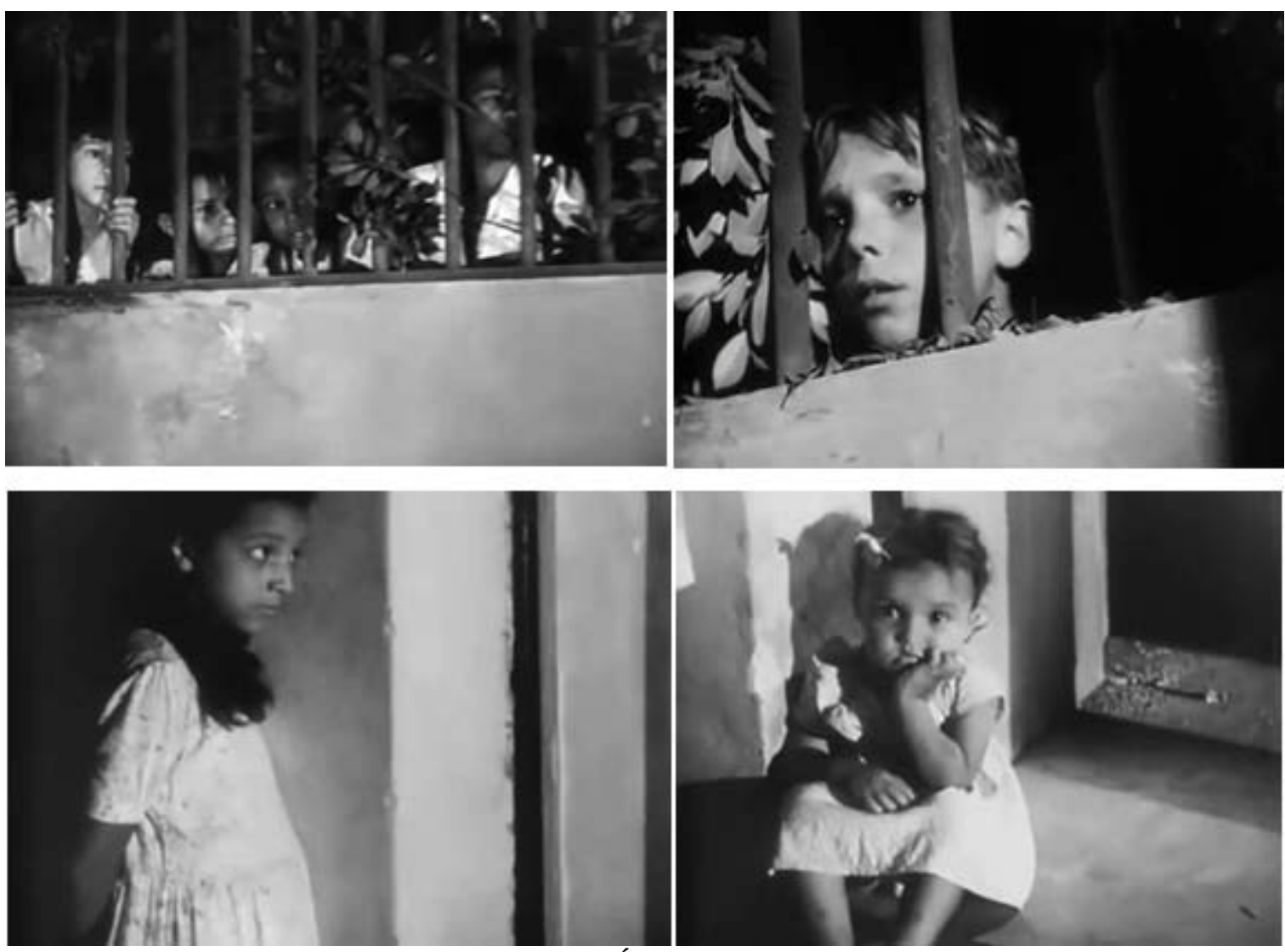

Fonte: 0 Ébrio (1946).

A menina com a mão no queixo surge exatamente quando Celestino profere as palavras: "quando eu morrer". Como sua sucessora na ordem da pureza, a criança alivia o sentido de tragédia e traz autenticidade à cena. A maior aproximação da câmera nos rostos das crianças foi um privilégio que nem o astro teve na sequência final. Elas surgem como sinal de esperança e pureza, algumas delas atrás de grades, longe do ambiente de degradação do bar.

\section{Considerações finais}

A transposição da canção, aliada ao estrelismo, torna os sons mais importantes do que as palavras, invertendo a tendência geral do filme de frisar o dizer. Nesse sentido, a música surge como fator compensador do tempo presente. Assim, ocorre uma inversão provisória em relação ao papel preponderante do dizer - característico da transposição teatral. Quando a canção toma o comando (CHION, 2002), o fundo sonoro torna-se o pivot do desenvolvimento psicológico do personagem. Trata-se de um momento de ápice da 
narrativa. Dessa forma, a música evoca toda uma atmosfera, delineia sentimentos, conflitos e estados psicológicos. É como se apenas a sensibilidade convertida em sons pudesse dar conta de expressar o drama do personagem. O ápice da ação dramática do Ébrio é a apresentação da canção, por sua capacidade de desnudar a alma humana e permitir a revelação daquilo que é de difícil expressão. Assim, a música torna-se elemento fundante e constituinte da narrativa, a completar a base dramatúrgica. É neste momento de performance musical que há, como diz Nilthe Pirotta (1992), uma união entre a estrutura musical, a manifestação do texto e a ação dramática centrada na canção.

Contudo, a canção reitera uma série de repetições já vistas. Nesse sentido, não há surpresa para o público que espera uma história o mais longa possível para prolongar sua emoção (MEYER, 1996). Nesse sentido, a repetição a intervalos regulares não procura explodir em um desfecho inesperado, mas produzir satisfações contínuas e renováveis (ECO, 2004). Se talvez o desfecho da trama não importasse para os conhecedores da história, era preciso esperar o filme inteiro para saciar a curiosidade de ver e ouvir Vicente Celestino cantar a música tema. Elaborado em torno dessa expectativa, $O$ Ébrio nasce híbrido em torno de sua origem musical. Nesse sentido, a obra é estruturada em função de outra mídia, como um tipo de mídia de redundância da transposição musical.

A hibridação do filme em relação à canção tema não ocorria só no cinema. Na peça de teatro há, inclusive, uma indicação de uma pausa na trama para ouvir os discos de Celestino, com a seguinte indicação: “Em todas as mutações deverão ser tocados vários trechos de músicas de autoria de Vicente Celestino." (O ÉBRIO, 1941). Antevendo o desejo de explorar a famosa canção apenas no final da trama, há uma deixa atenta que realça a expectativa do público: "Havendo também grandes aplausos só não poderá ser tocado $O$ Ébrio que é para o final da peça". Nesse sentido, a paralisação da narrativa para ouvir o disco de Celestino cumpria já um sentido intermidiático em relação à música no enredo teatral.

Esses exemplos não encerram todo o processo intermidiático do Ébrio. Durante a exibição cinematográfica, surgia uma possibilidade ímpar de lidar com a transposição musical e com a presença em cena do ator teatral em relação ao hic et nunc. Alice Gonzaga (1987) contou que, em algumas cidades do país, os projecionistas eram obrigados a voltar o filme várias vezes na cena final, devido à ameaça do público de quebrar a sala de cinema. Verdadeira ou não, essa historieta diz bastante sobre os mecanismos de um quase delayed cinema (MULVEY, 2006) ao vivo, revelando a importância da performance teatral para o fã. 0 termo sintetiza um atraso intencional na sequência fílmica, quando se congela por alguns 
instantes a imagem da estrela na narrativa. A contemplação desses instantes tem sua temporalidade ampliada através do uso do close up e da capacidade das atrizes fazerem poses para a câmera. Para Mulvey (2006), a técnica possibilita a ampliação do status iconográfico da estrela ao misturar a performance ficcional interna e externa com as fronteiras entre a atriz e a personagem. Portanto, esse desejo do público de apreender a imagem do ídolo na tela era incorporado de maneira intermidiática pelo próprio Vicente Celestino durante o lançamento do filme. Ele fez uma maratona musical em vários estados do sudeste, sul e nordeste. Depois da exibição do Ébrio, Celestino cantava a canção-título ao vivo nas salas de cinema, acompanhado de um piano (ABREU, 2003). Nesse caso, a própria exibição engrandecia-se da presença em cena do ator no tempo presente, não mais como fator compensador, mas global. Essa estratégia possibilitava ao fã ver Vicente Celestino na ficção e ao vivo no cinema, dando evasão a seu desejo de aprisionar a imagem do ídolo, tal como descrita por Laura Mulvey (2006). Nesse sentido, o estrelismo não só modificava a configuração da performance musical, mas esse tipo de exibição do astro ao vivo criava uma nova transposição musical da transposição cinematográfica.

\section{Referências}

ABREU, G. A vida de Vicente Celestino. São Paulo: Cupolo, [194-?a].

ABREU, G. Alma de palhaço. São Paulo: Cupolo, [195-?].

ABREU, G. Minha vida com Vicente celestino. São Paulo: Butterfly, 2003.

ABREU, G. O Ébrio. São Paulo: Cupolo, [194-?b].

ADAMATTI, M. M. A crítica cinematográfica e o star system nas revistas de fãs: a Cena Muda e Cinelândia (1952-1955). 2008. Dissertação (Mestrado em Ciência da Comunicação) - Escola de Comunicações e Artes, Universidade de São Paulo, São Paulo, 2008.

BAZIN, A. Cinema e teatro. In: BAZIN, A. 0 cinema: ensaios. São Paulo: Brasiliense, 1991.

BENJAMIN, W. A obra de arte na era da reprodutibilidade técnica. In: LIMA, L. C. Teoria da cultura de massa. São Paulo: Paz e Terra, 2000.

BOLTER, J. D; GRUSIN, R. Remediation: understanding new media. Cambridge: MIT Press, 2000.

CELESTINO, V. o Ébrio. São Paulo: RCA Victor, 1935. 1 disco sonoro. 
CHION, M. La comedie musicale. Paris: Cahiers du Cinéma, 2002.

CLÜVER, C. Inter textus/ inter artes/ inter media. Aletria, Belo Horizonte, v. 14, p. 10-41 jul./dez., 2006.

DECORDOVA, R. Picture personalities: the emergency of the star system in America. Chicago: University of Illinois Press, 2001.

DINIZ, T. F. N.; VIEIRA, A. S. Intermidialidade e estudos interartes: desafios da arte contemporânea. Belo Horizonte: Rona, 2012.

DYER, R. A Star is Born and the construction of authenticity. In: GLEDHILL, C. Stardom industry of desire. London/New York: Routledge, 1991a. p. 136-144.

DYER, R. Charisma. In: GLEDHILL, C. Stardom - industry of desire. London/New York: Routledge, 1991b. p. 58-61.

DYER, R. Stars. London: British Film Institute, 2004.

ECO, U. Retórica e ideologia em Os mistérios de Paris de Eugène Sue. In: ECO, U. Apocalípticos e integrados. São Paulo: Perspectiva, 2004.

FEUER, J. The self-reflective musical and the myth of entertainment. In: ALTMAN, R. (Org.). Genre: the musical. London: Routledge, 1981.

GONZAGA, A. 50 anos de Cinédia. Rio de Janeiro: Record, 1987.

GUERRA, G. Vicente Celestino o hóspede das tempestades. Rio de Janeiro: Record, 1994.

KIVY, P. Authenticities: philosophical reflections on musical performance. London: Cornell University Press, 1997.

LIMA, S. A. Performance \& interpretação musical: uma prática interdisciplinar. São Paulo: Musa/Faculdade de música Carlos Gomes, 2006.

MEYER, M. Folhetim: uma história. São Paulo: Cia das Letras, 1996.

MONCORVO, S. Artistas de teatro e artistas de cinema. A Cena Muda, Rio de Janeiro, n. 1079, p. 20-21, 25 nov. 1941.

MORIN, E. Cultura de massas no século XX: neurose. Rio de Janeiro: Forense Universitária, 2005.

MOSTAÇO, E. et al. Sobre performatividade. Florianópolis: Letras contemporâneas, 2009.

MÜLLER, J. E. Intermidialidade revisitada: algumas reflexões sobre os princípios básicos desse conceito. In: DINIZ, T. F. N.; VIEIRA, A. S. Intermidialidade e estudos interartes: desafios da arte contemporânea. Belo Horizonte: Rona, 2012. v. 2, p. 75-95. 
MULVEY, L. Death 24x a second: stillness and the moving image. London: Reaktion Books, 2006.

O ÉBRIO [filme]. Direção: Gilda de Abreu. Produção: Gilda de Abreu e Ademar Gonzaga. Intérpretes: Vicente Celestino; Alice Archambeau; Rodolfo Arena; Victor Drummond; Manuel Vieira; Walter D’Ávila. Roteiro: Gilda de Abreu. Música: Vicente Celestiono e Júlio Cristobal. Rio de Janeiro: Cinédia, 1946. Filme (125 min), p/b. Baseado na peça teatral “0 Ébrio" de Vicente Celestino.

O ÉBRIO [teatro]. Autoria: Vicente Celestino. Estreia: Teatro Carlos Gomes. Companhia Vicente Celestino. 1941.

O ÉBRIO [telenovela]. Direção: José Castellar e Heloisa Castellar. Produção: Otávio da Graça Mello. Intérpretes: Alvo Vianna, Arnaldo Fernandes, Arnaldo Weiss, Berta Zemel. Roteiro: José Castellar e Heloísa Castellar. São Paulo: TV Paulista, 1965-1966. Telenovela (75 capítulos). Baseada na peça teatral "O Ébrio" de Vicente Celestino.

PAIVA, S. C. História ilustrada dos filmes brasileiros. Rio de Janeiro: F. Alves, 1989.

PETHÖ, A. Cinema and intermediality: the passion for the in-between. Newscastle: Cambrigde Scholars Publishing, 2011.

PIROTTA, N. M. 0 melos dramático: pequena introdução ao estudo das relações dramamúsica no teatro. 1992. Dissertação (Mestrado em Artes) - Escola de Comunicações e Artes, Universidade de São Paulo, São Paulo, 1992.

PIZOQUERO, L. M. Cinema e gênero: a trajetória de Gilda de Abreu (1904-1979). 2006. Dissertação (Mestrado em Multimeios) - Instituto de Artes, Universidade Estadual de Campinas, Campinas, 2006.

PORTA ABERTA. Composição: Vicente Celestino. Intérprete: Vicente Celestino. 1946.

RAJEWSKY, I. A fronteira em discussão: o status problemático das fronteiras midiáticas no debate contemporâneo sobre intermidialidade. In: DINIZ, T. F. N.; VIEIRA, A. S.

Intermidialidade e estudos interartes: desafios da arte contemporânea. Belo Horizonte: Rona, 2012.v. 2, p. 51-73.

TARUSKIN, R. Text and act: essays on music and performance. New York: Oxford University Press, 1995.

TINHORÃO, J. R. Música popular: do gramofone ao rádio e TV. São Paulo: Ática, 1981. 


\title{
Cross Roads among intermediality, star system and music in $O$ Ébrio by Gilda de Abreu
}

\begin{abstract}
In 1935, the tenor Vicente Celestino has released the song $O$ Ébrio. Taking advantage of the great success that was achieved, the song was transposed to the universe of theater, cinema, literature, and tv soap opera throughout thirty years. The article takes the intermidiality, the concept of transposition and the star system as an analysis tool of $O$ Ébrio, by Gilda de Abreu. Based on the construction of Vicente Celestino's persona in the materiality of the movie, in the lyric self of the song and in the representation of the actor's media life, the objective is to demonstrate how the star presence in the screen, in musical sequences along with intermedial transposition become present in the cinematographic form.
\end{abstract}

\section{Keywords}

O Ébrio. Gilda de Abreu. Vicente Celestino. Intermediality.

Recebido em 27/07/2017

Aceito em 02/11/2017 